\title{
Effect of Some Gastro-Intestinal Nematodes Infection on Hematocrit Values in Goat, Sheep, Horse, Donkey and Cattle at Nyala City, South Darfur State, Sudan
}

\author{
Sharaf Y. Mohammed ${ }^{1}$, Eias Elzein, I Osman ${ }^{2 *}$, Shima M. Joma ${ }^{1}$, Fatima Musa Elhaj Mohammed ${ }^{3}$ \\ ${ }^{1}$ Veterinary Hospital, Ministry of Animal Recourse, Fishers and Rang Land, Nyala, Sudan \\ ${ }^{2}$ Department of clinical studies, Faculty of Veterinary Science, University of Nyala, Nyala, Sudan \\ ${ }^{3}$ Nyala Veterinary Research Laboratory, Nyala, Sudan \\ *Corresponding Author \\ Eias Elzein, I Osman
}

Email: Eiasalzain66@yahoo.com

\section{Article History}

Received: 04.05.2020

Accepted: 12.05 .2020

Published: 22.05.2020

\begin{abstract}
The aim of this study was to evaluate the effect of nematodes infection on pcv value in Goats, Sheep, Horse, Donkey and Cattle's. A total of 469 samples of faecal and blood were collected and transported to laboratory for detection of nematodes eggs and determine pcv value. The results obtained revealed that the higher prevalence rate of nematodes in study animals was on donkey when compared with others. The prevalence rate was higher in summer season than other autumn and winter. The effect of nematodes infection on PCV was found significantly lower $(\mathrm{P}<0.05)$ in Haemonchus spp, Trichostrongylus spp and Strongyloides spp when compared with Ascaris spp, Strongylus spp and Oxyuris spp.

Keywords: Goats, Sheep, Horse, Donkey, Cattle, nematodes and Hematocrit.
\end{abstract}

\section{INTRODUCTION}

The gastrointestinal (GI) nematodes are the important parasites of all regions across the tropics and sub-tropic countries like Sudan. They cause low productivity due to stop growth, poor weight gain, feed utilization, feeding and water intake, lower meat, wool and milk production, cost of treatment and mortality in young animals [1]. The epidemiology of gastrointestinal tract parasites in livestock varied depending on the local climatic conditions, such as humidity, temperature and rainfall, in addition to other factor such as vegetation and management practices. These factors largely determine the incidence and severity of various parasitic diseases in a region [2]. Diagnosis of gastrointestinal nematode infections plays a major role in investigating parasite epidemiology. The anti-mortem diagnosis of nematode infections in livestock has been based on the detection of nematode eggs or larvae in the feces by microscopic examination using flotation methods [3].

Determining blood parameters is helpful in assessing the health status of animals. There is many diseases lead to anemia, for examples of which include: helminthosis, trypanosomosis, and tick-burden and tick-borne infections such as babesiosis and anaplasmosis [4]. Hematocrit (PCV) is one of laboratory diagnosis of anemia and can be performed in most rural settings where methods of $\mathrm{Hb}$ concentration determination are unavailable and rough estimates are made using observed PCV values, which is a much simpler and cheaper approach. In rural African human medicine clinical practices, haematocrit (PCV) values are commonly used because they are easy and cheaper to perform using manual techniques [5]. The aim of this article to determining the effect of gastro-intestinal nematodes infection on Hematocrit values in Goats, Sheep, Horse, Donkey and Cattle.

Copyright @ 2020: This is an open-access article distributed under the terms of the Creative Commons Attribution license which permits unrestricted use, distribution, and reproduction in any medium for non commercial use (NonCommercial, or CC-BY-NC) provided the original author and source are credited. 


\section{Materials AND Methods \\ Study Area}

The present study was conducted in year 2014 - 2016 at Nyala Veterinary Research Laboratory, Nyala, Sudan. It is located between latitudes $8^{\circ} 30$ and $13^{\circ} 30$ North and longitudes $22^{\circ}$ and $28^{\circ}$ east.

\section{Study Design}

All data were collected from Nyala Veterinary Research Laboratory result registration records during period from January, 2014 to December, 2016. Fresh faecal samples were collected directly from the rectum of 469 animals using gloved hand and placed into universal bottles. In the laboratory, faecal samples were examined for the detection of nematode eggs employing standard procedures of flotation by using sodium chloride $(\mathrm{NaCl})$ as flotation fluid [6]. A total of 469 blood samples were taken. $5 \mathrm{ml}$ of blood were withdrawn from the jugular vein using sterile syringes. The blood was immediately transferred to heparinized containers. The samples were then transferred to the Laboratory. Blood were taken from the heparinized containers in a heparinized capillary tube to determine packed cell volume (PCV). The capillary tube was centrifuged at $1500 \mathrm{rpm}$ for 5 minutes then the value of PCV was determined using a micro haematocrit reader [7]. All PCV and faecal results were registried in registration records. All data were divided according to season into: Summer (February - June), autumn (July - November) and winter (December January).

\section{Statistical Analysis}

Data were tabulated and analyzed using descriptive statistics such as percentage by software Microsoft Excel, 2007 and SPSS (Statistical Package for Social Sciences) Version 16. P value less than 0.05 was considered as statistically significant.

\section{RESUlTS}

Out of 548 faecal samples 469 were found to be positive with various GI nematodes infection contributing a prevalence rate of $85.57 \%$. The results showed that the higher prevalence rate in study animals was on donkey when compared with goat, horse, cattle and sheep $(34.3 \%),(33.7 \%),(16 \%),(15.1 \%)$ and $(0.9 \%)$ respectively. On the other hand, the Ascaris spp registered higher number of infection when compared with Strongylus spp, Haemonchus spp, Oxyuris spp, Trichostrongylus spp and Strongyloides spp (153), (95), (94), (63), (37) and (27) respectively. Otherwise, the higher prevalence rate was showed in summer season when compared with autumn and winter (43.5\%), (32.2) and (24.3) respectively. The effect of nematodes infection on PCV was found significantly lower $(\mathrm{P}<0.05)$ in Haemonchus spp, Trichostrongylus spp and Strongyloides spp when compared with Ascaris spp, Strongylus spp and Oxyuris spp (27.16 \pm 0.79$),(27.46 \pm 0.96),(27.89 \pm 1.46),(29.33 \pm 0.57),(29.73 \pm 0.62)$ and $(29.76 \pm 0.74)$ respectively.

Table-1: Prevalence of Nematodes infection on ruminant and equine animals

\begin{tabular}{|c|c|c|c|c|c|c|c|}
\hline Helminthes & $\begin{array}{l}\text { Cattles } \\
\text { No. +ve (\%) }\end{array}$ & $\begin{array}{l}\text { Goats } \\
\text { No. +ve (\%) } \\
\end{array}$ & $\begin{array}{l}\text { Sheep } \\
\text { No. +ve (\%) }\end{array}$ & $\begin{array}{l}\text { Donkey } \\
\text { No. +ve (\%) } \\
\end{array}$ & $\begin{array}{l}\text { Horse } \\
\text { No. +ve (\%) } \\
\end{array}$ & $\begin{array}{l}\text { Camel } \\
\text { No. +ve (\%) }\end{array}$ & Total \\
\hline Ascaris spp & $43(60.6)$ & $40(25.3)$ & - & $45(28)$ & $25(33.3)$ & - & 153 \\
\hline Strongyloides spp & $3(4.2)$ & $20(12.7)$ & - & $3(1.9)$ & $1(1.3)$ & - & 27 \\
\hline Haemonchus spp & $4(5.6)$ & $86(54.4)$ & $4(100)$ & - & - & - & 94 \\
\hline Strongylus spp & - & - & - & $75(46.6)$ & $20(26.7)$ & - & 95 \\
\hline Oxyuris spp & - & - & - & $36(22.4)$ & $27(36)$ & - & 63 \\
\hline Trichostrongylus spp & $21(29.6)$ & $12(7.6)$ & - & $2(1.2)$ & $2(2.7)$ & - & 37 \\
\hline Total & $71(15.1)$ & $158(33.7)$ & $4(0.9)$ & $161(34.3)$ & $75(16)$ & - & 469 \\
\hline
\end{tabular}

No $=$ Number, $\mathrm{spp}=$ species, $\%=$ percent,$+\mathrm{ve}=$ positive

Table-2: Prevalence of Nematodes infection according to season

\begin{tabular}{|l|l|l|l|l|}
\hline Helminthes & $\begin{array}{l}\text { Summer } \\
\text { No. +ve (\%) }\end{array}$ & $\begin{array}{l}\text { Autumn } \\
\text { No. +ve (\%) }\end{array}$ & $\begin{array}{l}\text { Winter } \\
\text { No. +ve (\%) }\end{array}$ & Total \\
\hline Ascaris spp & $72(35.3)$ & $53(35)$ & $28(24.6)$ & 153 \\
\hline Strongyloides spp & $17(8.3)$ & $7(4.6)$ & $3(2.6)$ & 27 \\
\hline Haemonchus spp & $22(10.8)$ & $33(21.9)$ & $39(34.2)$ & 94 \\
\hline Strongylus spp & $41(20.1)$ & $33(21.9)$ & $21(18.4)$ & 95 \\
\hline Oxyuris spp & $42(20.6)$ & $10(6.6)$ & $11(9.6)$ & 63 \\
\hline Trichostrongylus spp & $10(4.9)$ & $15(9.9)$ & $12(10.5)$ & 37 \\
\hline Total & $\mathbf{2 0 4 ( 4 3 . 5 )}$ & $\mathbf{1 5 1 ( 3 2 . 2 )}$ & $\mathbf{1 1 4 ( 2 4 . 3 )}$ & $\mathbf{4 6 9}$ \\
\hline
\end{tabular}

No $=$ Number, $\mathrm{spp}=$ species, $\%=$ percent,$+\mathrm{ve}=$ positive 
Table-3: Effect of Nematodes infection (Means \pm SE) on PCV value

\begin{tabular}{|l|l|}
\hline Helminthes & PCV \% \\
\hline Ascaris spp & $29.33 \pm 0.57$ \\
\hline Strongyloides spp & $27.89 \pm 1.46$ \\
\hline Haemonchus spp & $27.16 \pm 0.79$ \\
\hline Strongylus spp & $29.73 \pm 0.62$ \\
\hline Oxyuris spp & $29.76 \pm 0.74$ \\
\hline Trichostrongylus spp & $27.46 \pm 0.96$ \\
\hline P $\leq \mathbf{0 . 5}$ & $\mathbf{0 . 0 4 5}$ \\
\hline
\end{tabular}

$\mathrm{spp}=$ species, $\mathrm{p}=$ significant, $\%=$ percent, $\mathrm{SE}=$ Standard Error

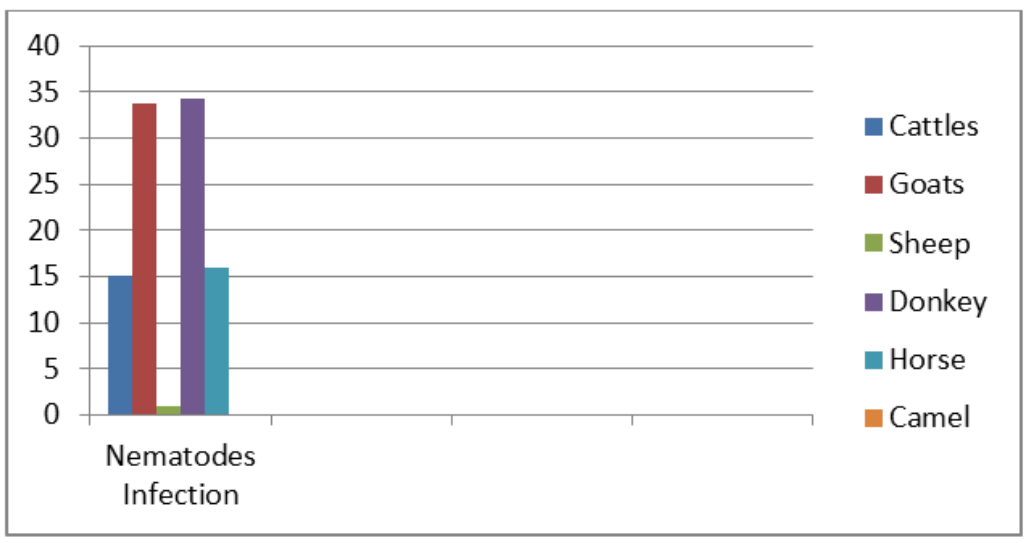

Prevalence of Nematodes infection on ruminant and equine animals

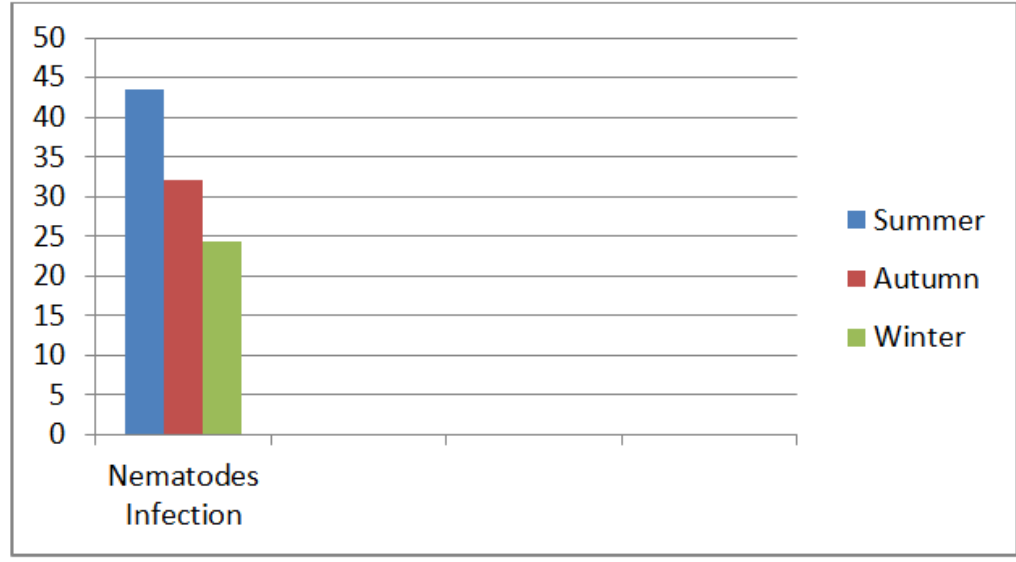

Prevalence of Nematodes infection according to season:

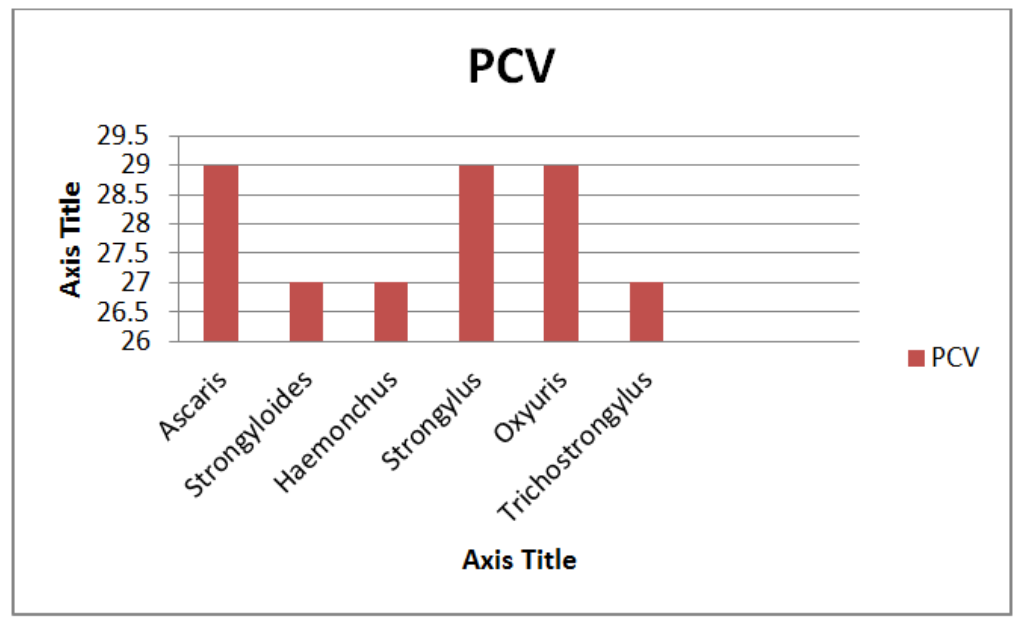

Effect of Nematodes infection on PCV values 


\section{DisCUSSION}

This study showed that prevalence rate of nematodes were higher on donkey than other animals because, Darfur region is one of the most heavily populated regions with animals especially equines. However, Donkeys are more susceptible to infection due to represent an important aspect of small holder farming system especially in rural communities and hamlets, they are used for conveying people, goods, and farm inputs and outputs to and from farms [810]. In addition to engaged in work for long hours with maltreatment, poor management conditions, overladen and feed on less nutritive garbage $[11,12]$. This study showed a higher level of prevalence rate in summer when compared with autumn and winter. These high results related to high infection of Ascaris spp. It might be due to hot humid climate in summer season provides favorable environment for the survival and development of parasitic larvae and may reach the infective stage within 1 to 3 months (or more) depending on temperature [13].

The PCV values were observed higher decrease in Haemonchus spp, Trichostrongylus spp and Strongyloides spp when compared with other nematodes in this study. The parasitic stage of Haemonchus and Trichostrongylus spp suck blood and caused hemorrhage in GI so, that anemia is distinct symptom [14]. When blood loss continuous iron deficiency and lead to decrease of PCV and indicated by low plasma iron concentration [15]. Furthermore, Strongyloides spp lead to decrease PCV value may be due to blood loss owing to migration from side of penetration until its arrival at site of infection in host [16].

\section{CONCLUSION}

From the present study, it is concluded that the higher prevalence rate of nematodes in study animals was on donkey when compared with others. The prevalence rate was higher in summer season than other autumn and winter. The effect of nematodes infection on PCV was found significantly lower $(\mathrm{P}<0.05)$ in Haemonchus spp, Trichostrongylus spp and Strongyloides spp when compared with Ascaris spp, Strongylus spp and Oxyuris spp. So, iron should be considered when treating bloodworm in domestic animals because there is relationship between hemoglobin concentration and fertility.

\section{ACKNOWLEDGEMENTS}

The authors thanks the authorities of Nyala Veterinary Research Laboratory for cooperated during the period of data collection.

\section{REFERENCES}

1. Paddock, R. (2010). Breed, Age and Sex Wise Distribution of Haemonchus contortus in Sheep and Goats in and around Rawalpindi Region, Pakistan. Medical Veterinary Journals, 12:60-63.

2. Takelye, B. (1991). Epidemiology of endoparasites of small ruminants in sub-Saharan Africa. In: Proceedings of the 4th National livestock Improvement Conference, Addis Ababa, Ethiopia, 7-15.

3. Roeber, F., Jex, A. R., \& Gasser, R. B. (2013). Impact of gastrointestinal parasitic nematodes of sheep, and the role of advanced molecular tools for exploring epidemiology and drug resistance-an Australian perspective. Parasites \& vectors, 6(1), 153.

4. Nwoha, R. I. O., \& Anene, B. M. (2011). Changes in packed cell volume and haemoglobin concentrations in dogs with single and conjunct experimental infections of Trypanosoma brucei and Ancylostoma caninum. Phillipine Journal of Veterinary and Animal Sciences, 37(20), 151-158.

5. Quinto, L., Aponte, J. J., Menendez, C., Sacarlal, J., Aide, P., \& Espasa, M. (2006). Relatonship between haemoglobin and haematocrit in the defniton of anemia. Tropical Medicine and Internatonal Health, 11, 12951302.

6. Charles, M. (2006). Diagnostic veterinary Parasitology. 3rd edn. St. Louis, MO. Elsevier Science.

7. Abebew, D., Endebu, B., \& Gizachew, A. (2011). Status of parasitism in donkeys of project and control areas in central region of Ethiopia: a comparative study. Ethiopian Veterinary Journal, 15(2):45-55.

8. Regassa, F., Dhuguma, R., Sorry, T., \& Bzunesh, M. (2005). Prevalence of equine gastro-intestinal parasite in western high lands of Oromia, Ethiopia. Bulletin of Animal Health and Production Africa, 53, 161-166.

9. Hailu, Y. T., \& Ashenaf, H. T. (2013) Epidemiological study on gastrointestinal helminths of horses in arsi-bale highlands of Oromiya region, Ethiopia, Addis Ababa University, College of Veterinary Medicine and Agriculture. Ethiopian Veterinary Journal, 17(2), 51-62.

10. Parsani, H., Momin, R., Lateef, A., \& Das, H. (2013). Studies on gastrointestinal helminths of Equus acinus in North Gujarat, India, Egyptian Journal of Biology, 15(1).

11. Mekuria, S., \& Abebe, R. (2010). Observation on major welfare problems of equine in Meskan district, Southern Ethiopia, Livestock Research for Rural Development, 22(3).

12. Bogale, B., Sisay, Z., \& Chanie, M. (2012). Strongyle nematode infections of donkeys and mules in and around Bahirdar, Northwest Ethiopia. Global Veterinaria, 9(4), 497-501. 
13. Allan, R. P. N. (1998). Epidemiology, Diagnosis Control of Helminth Parasites of Swine, FAO Animal Health Manual 3th, Roma. 11.

14. Dargie, J. D., \& Ali Onby, E. W. (1975). Pathophysiology of single and challenge infections of Haemonchus contortus in Merino sheep: studies on red cell kinetics and the 'self-cure' phenomenon. International Journal for Parasitology, 5: 147-15.

15. Albers, G. A. A., \& Le Jambre, L. F. (1983). Erythrocyte potassium concentration: a simple parameter for erythropoiesis in sheep infected with Haemonchus contortus. Research in veterinary science, 35(3), 273-276.

16. Mansfield, L. S., Alavi, A., Wortman, J. A., \& Schad, G. (1995). Gamma camera scintigraphy for direct visualization of larval migration in Strongyloides stercoralis-infected dogs. American Journal of Tropical Medicine and Hygiene, 52, 236-240. 